DOI: $10.17516 / 1997-1370-0630$

УДК 165.243:323.285

\title{
The Philosophical Category of the Ideal in the Models of the Future State of the Religious Extremists
}

\author{
Tatiana V. Izluchenko, Denis N. Gergilev \\ and Andrei V. Bardakov* \\ Siberian Federal University \\ Krasnoyarsk, Russian Federation
}

Received 08.04.2019, received in revised form 04.06.2020, accepted 05.07.2020

\begin{abstract}
The article analyzes the philosophical category of the ideal in the models of the future state structure, which are developed by the religious extremists in the context of modern social reality as the implementation of the ideal. The research is based on the activities of the Hizb ut-Tahrir al-Islami terrorist organization in Siberia. It is aimed at identifying the components of the religious extremist associations' ideology of constructing a model of an ideal state. The socio-philosophical analysis of the ideology provisions and the hermeneutical approach to the manifestations of extremism serve the basis of the research methodology. The extremist ideas in religion are deviations from the norm and can arise in any religious tradition, thus expanding the scope of interpretations of religious law and positioning the existing situation in the religious community as untrue and distorted. The future state is represented by the extremists as an ideal social structure established on the principle of justice and in accordance with sacred precepts. The conflict of such worldview ideas as "it should be so" and "it is so" as well as the "perfectionist illusion" about an ideal society imply the possibility of creating an ideal world in modern social reality. Violence is understood as a necessary means to achieve this goal if other methods are ineffective. The authors characterize the similarities between the models of an ideal society developed by the religious extremism and the utopias in terms of content and interpretation, as well as religious extremist consciousness and utopian thinking in terms of structure and orientation. The ideologies of extremist associations embrace the understanding of the principle of justice, the idea of exclusivity, the model of the ideal, and the theological foundations of social actions. The tendency of thinking to utopian ideas, the intuitive assumption of the existence of an ideal, just society, and the conflict between "the proper" and "the existing" contribute to the spread of extremist ideas. Extremism uses the properties of consciousness: religiousness and thinking in absolute categories (in a destructive aspect in order to add naturalness to its ideas) and religious ideas (in order to justify illegal activities with a sacred will). The actions of the members of the extremist associations are given the status of free personal choice regarding the fulfillment of religious prescriptions and the divine will to create a world just society.
\end{abstract}

\footnotetext{
(C) Siberian Federal University. All rights reserved

* Corresponding author E-mail address: E-mail address: izluchenko@mail.ru, turilak@yandex.ru, kerpc@mail.ru ORCID: 0000-0001-5644-301X (Izluchenko); 0000-0003-4913-4803 (Gergilev); 0000-0002-4381-9652 (Bardakov)
} 
Keywords: ideal society, the principle of justice, utopia, religious extremism, caliphate, future state, religious extremist ideas, Hizb ut-Tahrir al-Islami.

Research area: history, culturology.

Citation: Izluchenko, T.V., Gergilev, D.N., Bardakov, A.V. (2020). The philosophical category of the ideal in the models of the future state of the religious extremists. J. Sib. Fed. Univ. Humanit. Soc. Sci., 13(7), 1126-1136. DOI: 10.17516/1997-1370-0630.

\section{Introduction}

In the modern world, there appear contradictory socio-cultural phenomena. Global changes aimed at unifying all mankind often provoke preservation and strengthening of regional cultures, acting as a catalyst for their political, social, and spiritual activities. Glocalization processes take place. Thus, religious extremist associations that have a local origin and defend a certain population group's interests develop the ideologies based on the corresponding creeds that claim the status of universal socio-philosophical concepts of the world order. They offer a philosophical interpretation of socio-cultural and political events, an understanding of truth and justice, as well as a model of the future ideal society and, as a result, the corresponding political regime. However, due to globalization, these ideas with their regional and national bases are spreading along the geographically remote territories. For example, the idea of building an Islamic theocratic state (caliphate), developed by the middle Eastern theologian T. al-Nabhani, became popular in Siberia.

The phenomenon of religious extremism is studied by E. Sergun (2012) from a legal aspect, which emphasizes the illegal nature of social actions. In the religious studies by $\mathrm{Ch}$. Winter and M. Juergensmeyer (Winter, Hasan, 2016; Juergensmeyer, 2015) the extremists are viewed as transformers of the religious tradition for their own political tasks. The cognitive approach developed by R. Khalil, L. Stankov, and L. Agnati (Khalil, Richa, 2018; Stankov, 2018; Agnati et al., 2017) emphasizes the deviations from the normal functioning of consciousness structures. Whereas the philosophical component is ignored, the issue of the ideal in religious extremism is built on the basis of the conflict of the proper and the existing and the ideas of "it should be" and "it is so". It is being developed in idealized visions of state and society, functioning under divine orders.

Our research is aimed at identifying the main components of the ideology of religious extremism leading to the construction of an ideal socio-political system. This justifies the importance of characterizing the formation of extremist ideas about the socio-political system, the philosophical analysis of the content of justice as a principle of the ideal society, and the indication of the practice of its implementation in modern social reality. One of the few organizations with a detailed model of the future structure is the Hizb ut-Tahrir al-Islami terrorist organization (Islamic Party of Liberation) $)^{1}$. The ideas are presented in the works of the founder T. al-Nabhani and the ideologist A. Zallum $^{2}$. The presented research is based on the hermeneutical approach to the manifestations of the religious extremist associations and the socio-philosophical analysis of the ideology provisions.

\section{Peculiar features of religious extremism}

Religious extremism is understood as a social phenomenon, having negative consequences for social stability, perceived by the majority of the state population as a threat to positive social development, and justifying deviant behaviour by fulfilling divine prescriptions. Ex-

\footnotetext{
1 Note: "Islamic Party of Liberation" ("Hizb ut-Tahrir al-Islami”) is recognized as a terrorist organization and its activities are prohibited by the Decision of the Supreme Court of the Russian Federation No GKPI 03-116 dated February 14, 2003. Available at: http://nac.gov.ru/zakonodatelstvo/sudebnye-resheniya/reshenie-verhovnogo-suda-rf-ot-14-fevralya. html (accessed 20 September 2018).

2 Note: the journal published in Russian and the translations published in Russian are recognized as extremist materials.
} 
tremist ideas in the religious consciousness are manifested in the refusal to accept alternative options and in the orientation towards disregard for the worldview balance. They are considered to be deviations from the norm by any religious tradition, but they are not viewed as unique by any of them. There is an expansion of interpretations of religious law and positioning of the existing tradition as untrue and distorted and the model proposed by religious extremism as an ideal society, commanded as sacred (Winter, Hasan, 2016). In the course of the involvement of the religious extremist associations focus on the ideological assumptions, positioning them as traditional religious ones. All cultural communities are self-determined through rational knowledge. The values and principles of a particular religion become "universal for them and act as vectors (and even forms) for rational knowledge" (Koptseva, 2015: 63).

For their emergence and strengthening of extremist ideas, the associations use the religious consciousness and the ability to think in absolute categories, masking them with natural properties of consciousness, which ensures the achievement of high absolute goals. They dictate to the participant the necessary preferences and desires, which he/she perceives as the result of his/her personal free choice and as the fulfillment of religious precepts. Extremist ideas are the result of the work of religious consciousness, an adaptive product relative to the phenomena of social reality. Social, political, economic, routine and spiritual factors can serve as catalysts.

At the same time, extremism is not explained by mere psychological processes. First of all, it is a social phenomenon, for which the context of activities and actions performed in relation to other people is important. R. Prus claimes that behaviour has its meaning only within a certain group, in which a person is aware of himself and interprets his/her actions in relation to certain conditions. Activity in an extremist association is accompanied by an intense sense of ideological fervor, a stable set of actions by which a person expresses his/her loyalty to the system. The concept of extremism expresses the view of the official majority on noticeable differences in thinking or be- haviour, defined as threats, insults, immorality, the views that can lead to negative consequences (Prus, 2005: 47-74).

Extremist ideas are irrational beliefs that reinforce the feelings of self-worth and intolerance of frustration. If the demands to oneself and the world are not met, then the situation is unbearable for a person. This leads to psychological outrage, amplified by the clash between subjective ideas about the world and objective reality. Failure to tolerate injustice in the world indicates that it is intolerable, provokes accusations and anger against other people, and requires correction of the existing situation. Building an ideal world serves as justification for various kinds of actions, including violence. At that the creation of a world corresponding to their desires and the establishment of social regulation are understood by the religious extremists as the norm, the fulfillment of the will of the sacred, but not a violent action destabilizing the social situation.

The extremists demonstrate their formed ideas about the world order, which they are ready to protect in all ways available to them. S. Oganesyan argues that the religious extremists are not people who have gone mad. They appear to be misguided individuals with a certain world of values and ideas about good and evil, justice and brotherhood instilled in them by their spiritual mentors (Oganesyan, 2017: 17). A. Kolnai calls the belief in the existence of a world without conflicts a "perfectionist illusion" (Kolnai, 1993). However, negative irrational beliefs lead to destructive socio-cultural and political phenomena. They do not tolerate alternative views. They limit the choice of decision-making and the development of adaptive programmes of consciousness. In this regard, such thinking can be called utopian, since it recognizes that the world should be different and focuses on human shortcomings, injustice, and inequality (Coates, 2016: 110-111).

The internal fanatical belief in the possibility of embodying absolute ideals and the existing objective reality come into conflict with such worldview ideas as "it should be so" and "it is so". Absolute ideals imply the possibility of an ideal world. It is unavoidable. Therefore, it must be created. The people who oppose it 
are either ignorant and in need of re-education or acting deliberately and must be destroyed. Like utopia, the idea of an ideal society of the religious extremists is despotic towards people who do not fit into the model. It also contains hidden moments that characterize the system of punishment and the ways to achieve power (Isaak, 2015: 329-330).

The ideology of the religious extremist associations is based on the "We - They" dichotomy. According to this dichotomy, people are divided into two categories as per the compliance of their behaviour and thinking with the ideological requirements. Depending on this prerequisite, various measures of coercion and punishment apply to people. The first category consists of the so-called true ones. Moral principles are applied to them, even if they violate the requirements imposed on them by ideology. The second is constituted by the infidels, which are understood by people devoid of reason. Therefore, the relationship with them has no regulators. The fight against them is understood as a confrontation with evil, which allows the use of violent measures, up to complete destruction. At the same time, the religious extremists show ruthlessness not only to those who are considered to be the enemies of the faith but also to themselves. This leads to a destructive effect on the psyche and social bonds.

The specific ideas endowed with religious justification, the corresponding style of thinking and behaviour suggest the existence of religious extremist consciousness. The religious consciousness that accepts the extremist ideas is not aware of the significance of the real state of things. It is unable to distinguish the truth from lies and misconceptions, internally empty and devoid of having an adequate idea of its place in the society. There is a certain category of people who are susceptible to ideas of this kind and prone to illegal behaviour. The consciousness of these people has deep psychological disorders of the paranoid or narcissistic types which were formed at the early stages of development and contribute to the adoption of xenophobic and nationalistic ideas, the division of people into "their own" and "someone else's" ones (Antonyan, Yurasova, 2010: 10).
People's minds differ in the degree of mental activity. As a result, they are more receptive and emotional, radically reacting to external stimuli than others.

\section{The interrelation between}

\section{the concepts of justice and the ideal}

Private property as a prerequisite for economic power and social inequality as its consequence are declared to be the key sources of injustice and, consequently, evil (Karpeev, 2015: 71). To define an ideal society, functioning on the principle of justice, it is necessary to specify the constituents of injustice and the ways to deal with it. In addition, for the success of the theory it is important for it to be realistically utopian. It should hyperbolize favorable situations of social reality, take into account the actual impact of injustice and the practice of relations between people, as well as contain specific social, political, and economic proposals. The religious extremists do not only develop the theory of the structure of an ideal society, define the content of the concept of "justice" and propose appropriate legal norms, but also formulate the ways to combat violations of justice. All social institutions of an ideal society are based on a system of punishment determined by the requirement of justice (Schaub, 2014: 413-419).

There are two aspects in the definition of "the ideal". According to the first one, the ideal is an identical concept of justice that contains an ethical component. The ideal is the norm. The second aspect regards a simplifying assumption and schematization of actual developments while abstracting from certain features. The ideal is a model. At the same time, moral idealization involves modeling of what people and their relationships should be like, as well as what society should be like. Social ontology, human capabilities, social institutions, cognitive structures, and everyday life are idealized (Mills, 2005). At the same time, utopia is "a dream of an ideal life in any scale and manifestations" (Egorov, 2007: 6). Religious and mythological elements turn the objective reality into a space for the experiments and prove the right to implement ideas. According to B.F. Egorov, utopia, on the one hand, is only a dream that 
will never be realized, and, on the other hand, it "offers its own project of implementation, built according to the drawings of the human mind and striving for implementation" (Sobolevskaya, 2009: 168).

In its turn, ideology is a complex of idealized theories related to various spheres of society, ways of their implementation, and philosophical justification. It includes both social situations and desired ones, a system of values and evaluations, and specific knowledge. It is based on distorted ideas, values, norms, and beliefs that express the experience of a small number of people only, but extend to the entire society. Ideology allows certain people to identify themselves with certain worldviews that cultivate the ideas of pleasure, exclusivity, and significance. For this, they adhere to the appropriate lifestyle and behaviour, perform the required actions. Social coherence is provided by a constructed reality based on a distortion of the image of the objective reality and is supported by a collective conscience.

Ideology creates ideas that have meaning, give pleasure, fullness, and harmony, supported by ideal objects and corresponding narratives, in which fantasy is intertwined with reality. Acceptance, rejection, creation, extinction, recognition, and inclusion are ideological operations that make up the ideological system of unification. Through them, the religious extremist association focuses its participants on achieving the desired result, maintaining practical arguments on the transformation of the society regarding the functional consequences (Rocha Costa, 2017). In addition, such speculative issues of a philosophical and theological nature as the attributes of Allah as well as the issues of free will are replaced by discursive practices. Specific concepts and situations are interpreted in accordance with the ideology in its most simplified form. This contributes to the required simplicity of perception of the ideological prerequisites and the awareness of their consistency and truth.

The ideology is based on the idea of its supporters' perfection, which requires the demonstration of conviction and belonging. They appear to have true knowledge, which puts them above other people and other ethical and legal norms. At the same time, their ideological opponents are demonized and positioned as less human, which makes it impossible to apply humanistic principles to them (Harrington, 2013). A. Ellis identifies variations in religiousness in any religious adherence: from absolute dogmatism to everyday religious belief, which indicates knowledge but not literal adherence to it (Ellis, 2004).

Eschatological tendencies can be distinguished in the process of constructing the model of an ideal just society. The ideologies of religious extremist associations represent the future state as a rebirth or an improved embodiment of the previously existing structure, a return to harmony that was previously achieved. In modern conditions, many unsolved questions are given the answers. At the same time, a number of contradictory points are noted. These are the following ones: 1) earlier attempts have nothing to do with this one; 2) incorrect interpretations of historic facts; 3 ) gradual implementation of the project; 4) a just state serves only its citizens; 5) adjustments are possible in the course of the implementation process (Epshtein, 2004: 114-115).

Ideologies articulate the set worldview frameworks and attitudes, define polarities in socio-political statements, which express the understanding of the issues of being and those of futurology. The ideas about the future are based on pointing out and exaggerating the issues of the present, which negatively affects the existing socio-political, economic, and spiritual situation (Glenn, 2012). The ontological dichotomy "We-They" expresses the provision that there is a real world, the inhabitants of which live according to divine prescriptions, and a false or wrong world with the people who feel lost. The categories of truth and justice and the existence of true being belong only to the "We" category.

At that, the truth is recognized as the knowledge transmitted by God and the knowledge reflecting the requirements for maintaining physical and mental health. Justice is the realization of this knowledge in everyday practice. It is embodied in the form of an ideal society. Social relations which are constructive for the individual and the society are implemented 
on the principles of justice. They involve not only people but supernatural agents as well. Possible violations of justice do not harm the socio-political structure that embodies the ideal. Building an ideal society involves mythologizing certain historic facts and heroizing certain actors who are active participants and spiritual leaders. Both data objectivity and objective implementation difficulties are ignored. This serves as an indicator of the utopian tendencies in the ideas about an ideal society as the embodiment of previously existing "Paradise", improved in accordance with the capabilities of modern scientific and technical civilization.

Creation of an ideal society and/or state is declared to be the goal of collective activity, which may or may not be implemented within a single generation. All active actors have a status role, the fulfillment of which is their goal within the framework of collective activity. According to N. Harrington, the inability to achieve this goal can lead to psychological breakdowns and refusal to perform duties. In this regard, the associations level the situations, resulting from this, by differentiating their goals from the goals of their participants. They motivate them and allow them to feel a sense of significance and to gain recognition (Harrington, 2018).

The ideology of a religious extremist association includes the developed socio-philosophical ideas along with the ideas of divine revelation and irrational beliefs. They often contain a reference not only to the fulfillment of a certain sacred mission but to scientific and technical developments as confirmations of their ideas. Along with the theological ideas, the existing philosophical interpretations of truth, justice, and ideality are included in an integral ideological system, which claims the status of a socio-philosophical conception.

\section{The ideal state of the Islamic extremists}

The tradition of Islam allows us to interpret and systematize religious and legal norms. Pluralism in the philosophical and theological sphere is a consequence of this. These are political issues that cause too many opposing opinions. The main prescripts were formulated on the basis of ijtihad. They are not regulat- ed in the Quran and Sunnah. Radical Islam is based on a literal interpretation of norms. Its "rather archaic requirements of pure religious law, when they are used in their pure form" (Yunusov, 2017) are untenable in the modern world. Any requirement to follow pure Islam is subject to changes in practice. The reference to belonging to the Islamic tradition is a means of justifying one's activities.

Islamic extremism asserts the supremacy of Islamic law. Secular law is rejected on the grounds of inferiority and being directed against God and his true believers. According to the ideologists of the Hizb ut-Tahrir al-Islami terrorist organization, it will be implemented only in the conditions of an Islamic theocratic state (caliphate), the unification of all Islamic lands, the universal establishment of prayer and Sharia law. Until then, true Muslims must fight against disbelief and promote the creation of a caliphate within the existing legislation of the states on the territories they operate on. M. Ahnaf identifies two probable scenarios that will lead to the polarization of society. The first one is the growing distrust of the existing government (Ahnaf, 2018). The other one is the ideological reorientation of part of the population. The transnational instrument of communication between all Muslims is the Muslim community itself (Ummah), its structure, historical and theological foundations.

At that, the future ideal state may include the territories with the Muslim population, but not historically Islamic, the territories that have never been governed by Sharia law (Siberia, for example). However, it is worth while noting that in most projects of this kind Siberia is not considered a territory, the inclusion of which is mandatory and should be taken into account. Thus, in the version of the Hizb ut-Tahrir al-Islami terrorist organization, Siberia is only a resource territory where certain activities can be carried out. These are hiding from law enforcement agencies, attracting new people and propagating their ideology.

Social reality is divided into the world of Islam, which already exists, spreads its influence and serves the basis for the future caliphate, and the world of non-believers, the representatives of which can either accept pure 
Islam or be enemies and demand destruction. According to E.N. Egorov, the members of the Hizb ut-Tahrir al-Islami terrorist organization refer to the prophet's actions aimed only at protesting against the authorities and at gathering the supporters. Therefore, they do not aim to seize power in the state and force the population to accept Islam. "The party adheres to the tactic of using 'soft power' to persuade people to come to power and change the government" (Egorov, 2017: 26). "Nusra", a non-violent coup d'etat supported by the population and paramilitary groups, is declared to be the most productive method. When rejecting the existing governmental system all the privileges and freedoms that it provides are used to their maximum.

The model of the future state is based on the idealization of not only the society itself but also of its individual representatives. The personality of the prophet Muhammad is being heroized. His qualities of being both Allah's messenger and a human being are hyperbolized, endowed with power (idealized physical powers), which other Muslims are unable to show. The way of life following the example of the prophet and Sharia law will be available to all citizens.

At the same time, it contains some social, political, and economic provisions that betray the realism of the idea:

A) Interpretation of historic facts. The future caliphate should become more perfect and just than the state of the first Muslims and avoid the splits in the Ummah ${ }^{3}$. According to the participants of this association, humanity goes through the following stages of historical development: 1) the prophet Muhammad's prophecy; 2) the time of the prophecy; 3) the caliphate that was replaced by the monarchy; 4) the time of the monarchy; 5) the period of the despotic rule; 6) the caliphate created by this terrorist organization as the end of history.

B) Separation of people. All people residing in the territory of the caliphate are divided

\footnotetext{
3 Note: by the decision of the Kalininsky district court of Ufa of the Republic of Bashkortostan dated July 29, 2009, the brochure "The Draft of the Constitution of the Islamic state of the Caliphate. Hizb ut-Tahrir. Approved publication" is recognized as an extremist material. Available at: http://minjust.ru/ ru/extremist-materials (accessed 30 September 2018).
}

into categories with certain responsibilities each. The first one includes citizens with equal rights regardless of religion or nation. They are both Muslims and non-Muslims: "bookish people" and pagans. They take part in the selection of the caliph, can hold any public office, have the representation of their interests in the Parliament (Majlis), pay appropriate taxes, and get a salary based on the income of the organization and the profitability of the employee. The Muslims have been receiving military training since the age of 15 to perform their religious duty of Jihad. They have their own representative body, the Shura. The second category consists of the jihadists (mujahideen), non-citizens of the caliphate residing in its territory under the agreement. There is no such agreement with Russia, the United Kingdom, France, and the United States. The third category is represented by the people with the permission to live and work in the caliphate.

C) Administrative and territorial structure. The whole territory is divided into wilayahs (provinces) on a regional basis, the wilayahs consisting of imalats (regions). Wilayahs are free to make decisions on administrative matters. The head of state is the caliph, who is elected by all citizens from two candidates. He commands the entire army, consisting of regular and reserve units, has the right to declare war and to make peace. They also report to the Majlis for their actions and receive recommendations and expert opinions on various management issues.

D) Economy. The economic system is based on the provision that Allah is the sole owner of everything, but people have certain rights. The types of property are the state property, which is collected through taxes, the public property, which consists of the profits of the Ummah, and the private property, which is constituted of the income of an individual. However, it is prohibited to accumulate funds without using them. This area is regulated by a single Public Bank. The Treasury is collected from trophies, jizya, kharaj, zakat, and 1/5 of the found wealth. Jizya is collected from all non-Muslim males. Zakat is paid by all Muslims. Kharaj is a land tax paid by everyone. 
The presented brief review of the project for the future caliphate of the Hizb ut-Tahrir al-Islami terrorist organization shows that it is positioned as an idealized state functioning on the principles of justice and equality and meeting the needs and interests of the representatives of modern society. T. al-Nabhani expressed a realistic utopian idea, leaving room for adjustments in the implementation process and maximally coordinating it with Sharia. Mukhkhabatov claims that the ideology of Hizb ut-Tahrir al-Islami is an anti-human and anti-social theory, despite the external progressiveness of its provisions. It is against individual freedoms of ownership, speech, and conscience and against national cultural heritage. The Muslims are given the right to think and act only within the framework of Sharia, and to use only Arabic (Mukhkhabatov, 2004: 12).

However, it is worth noting that with the large number of extremist Islamic associations and versions of the future society this model of the caliphate is the most meaningful. It considers issues of different areas. This largely explains the spread of the Hizb ut-Tahrir al-Islami terrorist organization in the world since the middle of the $20^{\text {th }}$ century as well as its systemic development. For example, the al-Ikhwan al-Muslimun terrorist organization (translated into English as "The Society of Muslim Brothers") has developed a method of seizing power in the state. S. Lacroix considers the mobilization of resources, which is based on the network nature of the relationships, to be a condition for the political success of this association's participants. In addition, it is claimed that "the movement has developed a broadly appealing discourse emphasizing the two fashionable values of post-Mubarak Egypt: revolution and Sharia" (Lacroix, 2016). However, its ideology lacks a realistic project of the future state structure, including the structure of political power and directions of activity. This is demonstrated by the political events in Egypt during the 20102013 period.

\section{Conclusion}

Summing up the above, it is worth while noting that modern globalization and glocalization processes lead to the emergence of various kinds of contradictory phenomena, which often cause negative consequences. Globalizing conditions result in spreading the glocalization ideas, aimed at strengthening regional culture and people's identity on any national and spiritual basis, to remote territories both historically and geographically. Understanding of the philosophical category of the ideal in religious extremism includes the interpretation of justice and injustice. At that all the negative phenomena of the modern world, regardless of people's belonging to a nation, race, or religion (hunger, disease, social inequality), are considered the matters of injustice. Justice is realized in pleasure, harmony, and significance of the participants of a certain religious extremist association only.

The ideal is embodied in the model of the ideal state, all components of which (including the leaders of the past and the present) are idealized. Building a given state, changing "it is so" to "it should be so" is positioned as the goal of the activity. In fact, this idea is utopian, since it neither adheres to practical reasoning nor focuses on a descriptive model. It contains specific instructions on how it should not be, but an abstract idea of how it will actually be. Religious extremist consciousness is identical to utopian thinking. It is convinced of the possibility of building an ideal state with an emphasis on human shortcomings, unfair punishment, and existing social inequality. At that, historical facts and objective conditions are either interpreted in accordance with the ideology or ignored.

\section{References}

Agnati, L., Marcoli, M., Agnati, U., Ferraro, L., Guidolin, D., Maura, G. (2017). The mis-exaptation of the prediction capability of humans and emergence of intolerant religious beliefs. In Neurology, Psychiatry and Brain Research, 23, 43-53. 
Ahnaf, M. (2018). Hizb al-Tahrir: Its Ideology and Theory for Collective Radicalization. In K. Steiner, A. Önnerfors, Expressions of Radicalization. Palgrave Macmillan.

Antonyan, Yu.M., Yurasova, E.N. (2010). Ekstremistskoe i terroristicheskoe povedenie s pozitsii glubinnoi psikhologii [Extremist and terrorist behaviour from the perspective of depth psychology]. In Scientific portal of the Russia Ministry of the Interior, 2, 10-13.

Coates, Jo. (2016). Utopia - An obsolete concept. In Techno-logical Forecasting and Social Change, 113, 110-111.

Epshtein, M.N. (2014). Religiia posle ateizma. Novye vozmozhnosti teologii [Religion after atheism. New features of theology]. Moscow: AST-Press.

Egorov, B.F. (2007). Rossiiskie utopii: Istoricheskii putevodite' [Russian Utopias: A Historical Guide]. St. Petersburg, Iskusstvo.

Egorov, E.N. (2017). "Khizb ut-Takhrir" na zapade: ideologiia i spetsifika deiatel'nosti ["Hizb utTahrir" in the West: Ideology and Specific Activities]. In Islamic studies, 2, 28-36.

Ellis, A. (2004). The road to tolerance. The philosophy of rational emotive behavior therapy. NewYork, Prometheus Books.

Glenn, J. (2012). Science fiction: The radium age. In Nature, 489, 204-205.

Harrington, N. (2013). Irrational Beliefs and Socio-Political Extremism. In Journal of Rational-Emotive \& Cognitive-Behavior Therapy, 31 (3), 167-178.

Isaak, R. (2015). Every utopia turns info dystopia. In Tourism Management, 51, 329-330.

Karpeev, E.P. (2015). O vozniknovenii utopii v chelovecheskom soznanii i ob utopii marksizma i religii [On the emergence of utopia in human consciousness and on the utopia of Marxism and religion]. In Eurasian Union of Scientists, 12, 70-73.

Khalil, R., Richa, S. (2018). On cognitive debiasing and the judgment of suicide-attackers À propos de la correction du biais cognitif et du jugement des agresseurs-suicidaires. In L'Encéphale. In Press.

Kolnai, A. (1993). The utopian mind and other essays. London, Athlone Press.

Koptseva, N.P. (2015). Otnoshenie religii i filosofii kak predposylka obnaruzheniia simvolov absoliutnoi istiny v sviashchennykh religioznykh tekstakh [The relation between philosophy and religion as a premise for discovering symbols of the absolute truth in holy religious texts]. In Bulletin of Tomsk State University, 392, 59-65.

Lacroix, S. (2016). Egypt's Revolutions. Politics, Religion, and Social Movements. New-York, Palgrave Macmillan.

Mills, Ch. (2005). "Ideal Theory” as Ideology. In Hypatia, 20, 165-184.

Mukhkhabatov, K.M. (2004). Sotsial'no-politicheskie faktory obrazovaniia religiozno-politicheskoi organizactsii "Khizb ut-Takhrir" i eio reaktsionnaia sushchnost (na primere Tadzhikistana) [Socio-political factors in the formation of the Hizb ut-Tahrir religious-political organization and its reactionary nature (on the example of Tajikistan)]: avtoref. na diss. ... kand. polit. nauk. Dushambe.

Oganesyan, S.S. (2017). Spetsifika religioznogo ekstremizma i terrorizma, kak istoricheski obuslovlennogo sotsial'no-politicheskogo iavleniia [The specifics of religious extremism and terrorism as a historically conditioned sociopolitical phenomenon]. In International Journal of Psychology and Pedagogy in official activities, 4, 14-18.

Prus, R. (2005). Terrorism, tyranny, and religious extremism as collective activity: Beyond the deviant, psychological, and power mystiques. In The American Sociologist, 36 (1), 47-74.

Rocha Costa, A. (2017). Situated Ideological Systems: a Formal Concept, a Computational Notation, Some applications. In Axiomathes, 27, 15-78.

Schaub, J. (2014). The Incompleteness of Ideal Theory. In Res Publica, 20 (4), 413-419.

Sergun, E.P. (2012). Sootnoshenie poniatii "religioznyi fundamentalism" i "religioznyi ekstremizm" [The Correlation of the Notions "Religious Fundamentalism" and "Religious Extremism"]. In Legal Culture, 2, 99-103.

Sobolevskaia, N.N. (2009). Review for the book: Egorov, B.F. Russian Utopias: A Historical Guide. St. Petersburg, Art, 2007. In Vestnik Novosibirskogo gosudarstvennogo universiteta. Ser. Istoriia, Filologiia, 2, 166-169. 
Stankov, L. (2018). Psychological processes common to social conservatism and terrorism. In Personality and Individual Differences, 120, 75-80.

Winter, Ch., Hasan, U. (2016). The Balanced Nation: Islam and the Challenges of Extremism, Fundamentatism, Islamism and Jihadism. In Philosophia, 44 (3), 667-688.

Yunusov, A.A., Abdurazakov, A.A. (2017). Bor'ba s religioznym ekstremizmom (obshcheteoreticheskii aspekt) [The fight against religious extremism (general theoretical aspect)]. In Bulletin of Economic Security, 1, 31-35.

Juergensmeyer, M. (2015). Religious Nationalism and the Secular State. International Encyclopedia of the Social \& Behavioral Sciences (Second Edition), 401-405.

\title{
Философская категория идеального в моделях будущего государства религиозных экстремистов
}

\author{
Т.В. Излученко, Д.Н. Гергилев, А.В. Бардаков \\ Сибирский федеральный университет \\ Российская Федерачия, Красноярск
}

\begin{tabular}{l}
\hline Аннотация. Статья посвящена анализу философской категории идеального \\
в моделях будущего государственного устройства, которые разрабатываются \\
религиозными экстремистами в контексте современной социальной реальности \\
как реализация идеального. Исследование основано на изучении деятельности \\
террористической организации «Хизб ут-Тахрир аль-Ислами» на территории \\
Сибири. Целью работы служит выявление составляющих компонентов \\
идеологии религиозных экстремистских объдднений, конструирующих \\
модель идеального государства. Социально-философский анализ положений \\
идеологии и герменевтический подход к проявлениям экстремизма находятся \\
в основе методологии исследования. Экстремистские идеи в религии являются \\
отклонениями от нормы и могут возникнуть в любой религиозной традиции, \\
расширяя область интерпретаций религиозного права и позиционируя \\
существующее положение в религиозном сообществе неистинным искаженным. \\
Будущее государство представляется экстремистами идеальным общественным \\
устройством, созданным на принципе справедливости и согласно священным \\
предписаниям. Конфликт мировоззренческих позиций «должно быть так» и \\
«так есть», наличие «перфекционалистской иллюзии» об идеальном обществе \\
подразумевают возможность создания идеального мира в современной \\
социальной действительности. Насилие понимается необходимым средством \\
достижения данной цели, если другие способы малоэффективны. Авторами \\
характеризуются сходства моделей идеального общества, разработанные \\
религиозным экстремизмом, и утопий по содержанию и интерпретациям, а \\
также религиозного экстремистского сознания и утопичного мышления по \\
структуре и направленности. Понимание принципа справедливости, идеи \\
исключительности, модели идеального и богословских основ социальных \\
действий содержатся в идеологиях экстремистских объединений. Склонность \\
мышления к утопичным идеям, интуитивное допущение существования \\
идеального, справедливого общества и конфликт между «должным» исущим»
\end{tabular} 
способствуют распространению экстремистских идей. Экстремизм использует свойства сознания: религиозность и мышление абсолютными категориями - в деструктивном аспекте для придания своим идеям естественности, а религиозные идеи - для обоснования противоправной деятельности священной волей. Действиям участников экстремистских объединений придается статус свободного личностного выбора, связанного с исполнением религиозных предписаний и Божественной воли по созданию всемирного справедливого общества.

Ключевые слова: идеальное общество, принцип справедливости, утопия, религиозный экстремизм, халифат, будущее государство, религиозные экстремистские идеи, «Хизб ут-Тахрир аль-Ислами».

Научные специальности: 07.00.00 - исторические науки, 24.00.00 - культурология. 